\title{
Taxonomic and trophic groups diversity of soil invertebrates positively respond to restoration of riparian forests
}

\author{
Stella Ferreira Biondi'; Rodrigo Lopes Ferreira ${ }^{2}$ \& Yasmine Antonini $^{1, \mathbb{}}{ }^{1}$ \\ ${ }^{1}$ Departamento de Biodiversidade Evolução e Meio Ambiente - UFOP. Campus Morro do Cruzeiro. Bauxita, Ouro Preto, MG, \\ Brazil. ${ }^{2}$ Centro de Estudos em Biologia Subterrânea, Setor de Zoologia Geral/DBI, Universidade Federal de Lavras. Lavras, \\ MG, Brazil.
}

\begin{abstract}
Aвstract. A successful restoration of riparian forests can recover the diversity of several groups of soil invertebrates. However, few studies have considered the recovery of the entire community of soil macrofauna and the relative effect in taxonomical and functional diversity. We evaluated how taxonomical diversity, in terms of abundance and richness, relates to trophic diversity in four patches of riparian forests that had been artificially recovered, and compared them to the reference site in Volta Grande Reservoir, Brazil. No relationship was found between taxonomic diversity and trophic diversity, suggesting functional redundancy among taxonomic groups. Nevertheless, we observed that the taxonomic group with more species presented higher trophic diversity than the rest, indicating low functional redundancy within this group. The abundance and the taxonomic and functional richness of the four restored sites was similar to the reference site. The forest recovery was efficient in recovering invertebrate soil community since the taxonomic and trophic composition recorded in our study were similar to the composition of natural areas. We emphasize the importance of studying edaphic fauna as a community in order to comprehend how it reacts to forest restoration.
\end{abstract}

[Keywords: tropical forest restoration, soil macrofauna diversity]

\begin{abstract}
Resumen. La diversidad de grupos taxonómicos y tróficos de los invertebrados del suelo responden positivamente a la restauración de los bosques riparios. Una restauración exitosa de los bosques ribereños puede recuperar la diversidad de varios grupos de invertebrados del suelo. Sin embargo, pocos estudios han considerado la recuperación de toda la comunidad de macrofauna del suelo y el efecto relativo en la diversidad taxonómica y funcional. Evaluamos cómo la diversidad taxonómica, en términos de abundancia y riqueza, se relaciona con la diversidad trófica en cuatro parches de bosques ribereños que habían sido recuperados artificialmente, en comparación con el sitio de referencia en el Embalse Volta Grande, Brasil. No se encontró relación entre la diversidad taxonómica y la diversidad trófica, lo que indica redundancia funcional entre grupos taxonómicos. Sin embargo, observamos que el grupo taxonómico con más especies presentó mayor diversidad trófica, lo cual indica una baja redundancia funcional dentro de ese grupo. La abundancia y la riqueza taxonómica y funcional de los cuatro sitios restaurados fueron similares al sitio de referencia. La recuperación del bosque recuperó eficientemente la comunidad los invertebrados del suelo, ya que la composición taxonómica y trófica registrada en nuestros de estudio fue similar a la composición de las áreas naturales. Enfatizamos la importancia de estudiar la fauna edáfica a nivel de comunidad para comprender cómo reacciona a la restauración forestal.
\end{abstract}

[Palabras clave: restauración de bosques tropicales, diversidad de la macrofauna del suelo]

\section{INTRODUCTION}

Over the last two decades, forest restoration focused on re-establishing vegetation with the expectation that the structural attributes needed by animal species will develop, allowing recolonization by native wildlife communities and restoration of the ecological functions that they provide (Kollmann et al. 2016). However, many restoration projects have failed to restore wildlife even when the physical environment and vegetation were restored (Sheean et al. 2012; Peipoch et al. 2015), mainly because of reduced recovered of habitat structure heterogeneity (Peipoch et al. 2015; Jones and Davidson 2016).

Editora asociada: María Semmartin Editora Junior: Mariana Tadey
Ecological restoration implies the recovery not only of vegetation, but of the whole set of attributes of the original ecosystem, in which soil macrofauna is included. Thus, if we want to infer whether forest ecosystems are really being restored by active restoration, we need to evaluate whether vegetation structure recovery is able to imply in the reestablishment of the ecological functions in the edaphic community (Kollmann et al. 2016). This new perspective, redirected studies on restoration ecology, increasing the approach of ecosystem functions since the last decade (Ruiz-Jaen and Mitchell Aide 2005). For this new approach, and due to the numerous functions that soil 
fauna performs for the ecosystems, Fraser et al. (2015) recommended to consider trophic structure and the use of soil invertebrates diversity as tools for investigating whether forests subjected to restoration processes were recovering those communities and its functions. Edaphic macrofauna can be an excellent bioindicator since it has a varied diet and is very sensitive to seasonality (Lavelle et al. 2006; Blankinship et al. 2011; Amazonas et al. 2017). However, if the goal is to use soil invertebrates as bioindicators of forest restoration success, values of richness and abundance of soil invertebrates alone are not good estimators. For example, according to Stork and Eggleton (1992), a particularly useful method to evaluate restoration success is to examine groups of invertebrate species (like guilds) that use the same trophic resource.

Resource partitioning by a greater number of species can favor the occurrence of an increased number of trophic groups, allowing the complete exploitation and/or use of the available resources with reduced competition (Petchey 2003; Heemsbergen et al. 2004). There is evidence of the existing relationship between species richness and trophic richness in ecosystems, which may be linked to important ecosystem services such as energy transfer and cycling of matter (Petchey 2003; Heemsbergen et al. 2004). Soil invertebrates also play important, but largely ignored, roles in the delivery of ecosystem services, both at local and landscape scales (Lavelle et al. 2006). From soil perspective, the invertebrates are key mediators of soil functionality, involved in a wide diversity of ecosystem engineering processes, such as increased soil fertility, biological control of pathogens and plant parasites, nutrient cycling, water filtration and soil formation (Barrios 2007; Dominati et al. 2010). From a community perspective, they affect primary production, directly, via soil herbivores, pathogens and mutualists, and indirectly, by decomposition of organic matter and the nutrients return to the plants (Sylvain and Wall 2011).

In this study, we evaluated the hypothesis that diversity of the soil invertebrates is related to trophic diversity and that restoration, after 10 years, will recover the community in riparian ecosystems. If our hypothesis is true, we expect that richness and abundance of trophic groups should be positively correlated to the richness and abundance of taxonomic groups of the entire community and that richness and abundance of taxonomic groups in restored sites will be like the reference site.

\section{Materials and Methods}

\section{Study sites}

The study was carried in the region of the Volta Grande Reservoir, in the states of Minas Gerais and São Paulo $\left(20^{\circ} 01^{\prime} 54^{\prime \prime}\right.$ S - $48^{\circ} 13^{\prime} 17^{\prime} \mathrm{W}$ ), Brazil (Figure 1). The average annual temperature is $23^{\circ} \mathrm{C}$ and the average annual precipitation is $1506 \mathrm{~mm}$ (Martins and Antonini 2016). Volta Grande Reservoir presents a Tropical AW Köppen climate (with a dry winter) (Alvares et al. 2014), and is situated in a landscape consisting mostly by pastures and monocultures (i.e., sugar-cane, rubber-tree plantations) (for more details, see Martins and Antonini 2016; Araujo et al. 2017). We randomly sampled five fragments of riparian forest (considered sampling sites) (average $17.7 \pm 4.86 \mathrm{ha}$ ), separated by at least $15 \mathrm{~km}$ (except for two sites) and with similar forest cover in the matrix $(\sim 30 \%)$. After 30 years of recovery, the landscape naturally became a mosaic of environments that strongly influenced the restoration of the riparian forest fragments. Most of the original riparian vegetation of the study area were removed and/or flooded during the construction of the reservoir. Thus, the geomorphology, hydrology, and vegetation had been altered. During the period between 1994 and 2004, about 35 tree species were planted in a single replanting event in four out the five studied sites since one of the studied sites was a 30-year secondary forest. Reforestation was carried out by planting nursery-grown seedlings of about 35 species, from seeds obtained in a nearby forest remnants.

\section{Sampling}

In the center of each sampling site, we stablished three linear transects, 50-m apart from each other and parallel to the water reservoir (Figure 2). Ten pitfall traps, $5 \mathrm{~m}$ apart from each other (Moldenke 1994) were installed along each transect, consisting of $0.07-\mathrm{m}$ diameter $(300 \mathrm{~mL}$ volume) plastic cups. Traps were filled once a month with $100 \mathrm{~mL}$ of ethylene glycol and remained seven days collecting invertebrate samples. We checked the samples monthly, between March 2013 and January 2014, always keeping the invertebrates collected preserved in alcohol $70 \%$ in individual recipes identified per month 


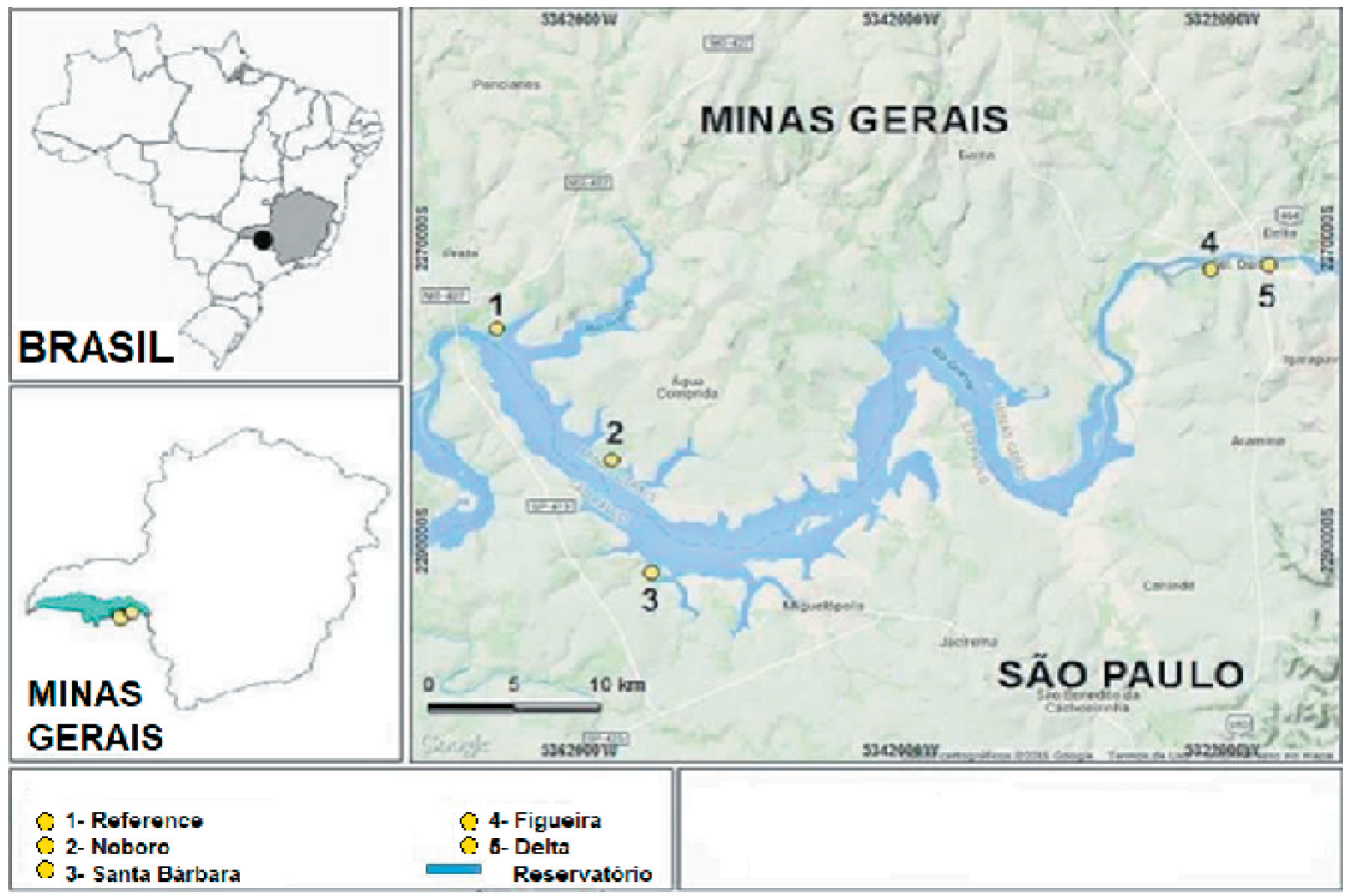

Figure 1. Map of the study area with the location of restored fragments of riparian forest in the Volta Grande Reservoir, Brazil.

Figura 1. Mapa del área de estudio con la ubicación de fragmentos restaurados de bosque ribereño en el Embalse Volta Grande, Brasil.

and year. Adult individuals were identified to the lowest taxonomic level possible and classified into 13 trophic groups (Table 1) (following Punzo and Fred 1994; Triplehorn and Johnson 2005; Lach et al. 2010; Baccaro et al. 2015) and sorted into morphospecies. In this work, each morphospecies were considered as a single species in the data analysis. The species were identified using taxonomic guides, and consulting the arthropod collection of Departamento de Biodiversidade, Evolução e Meio Ambiente of Universidade Federal de Ouro Preto (UFOP), Minas Gerais state, Brazil. Specialists identified some exemplars, especially for Hymenoptera, Diptera, Coleoptera and Araneae because these groups have more species in our samples. Voucher morphospecies were deposited at the Invertebrate Collection of the UFOP. For data analysis, were considered the most abundant groups and with well-known taxonomy, including 16 taxa: Blattodea, Coleoptera, Dermaptera, Diptera, Hemiptera, Hymenoptera, Lepidoptera, Orthoptera, Araneae, Opiliones, Pseudoscorpiones, Scorpiones, Chilopoda, Diplopoda, Mesogastropoda and Pulmonata. These taxa were chosen because they were in our samples.
Table 1. Trophic niche of the groups of macrofauna of soil, sampled in the restored areas of Volta Grande Reservoir, Brazil.

Tabla 1. Nicho trófico de los grupos de macrofauna de suelo, muestreado en las áreas restauradas del Embalse Volta Grande, Brasil.

\begin{tabular}{|c|c|}
\hline Trophic niche & Main food resource \\
\hline Coprophagous (Cop) & Dung of vertebrates \\
\hline Phytophagous (Phy) & Plant sap \\
\hline Frugivore (Fru) & $\begin{array}{l}\text { Fruits and fruit nectar } \\
\text { feeding }\end{array}$ \\
\hline Hematophagus (Hem) & Vertebrate blood feeding \\
\hline Herbivore (Her) & Leaf, wood and seed \\
\hline Mycethofageus (Myc) & Fungi farmer \\
\hline Nectarivore (Nec) & Flower nectar \\
\hline Omnivorous (Omn) & $\begin{array}{l}\text { Generalized feeding (more } \\
\text { than one trophic niche) }\end{array}$ \\
\hline Parasitoid (Par) & Have a host until its death \\
\hline Polynivore (Pol) & Flower pollen \\
\hline Primary predator (PP) & Primary consumers \\
\hline Secondary Predator (SP) & Predator of predators \\
\hline Saprophagus (Sap) & $\begin{array}{l}\text { Organic matter in } \\
\text { decomposition }\end{array}$ \\
\hline
\end{tabular}




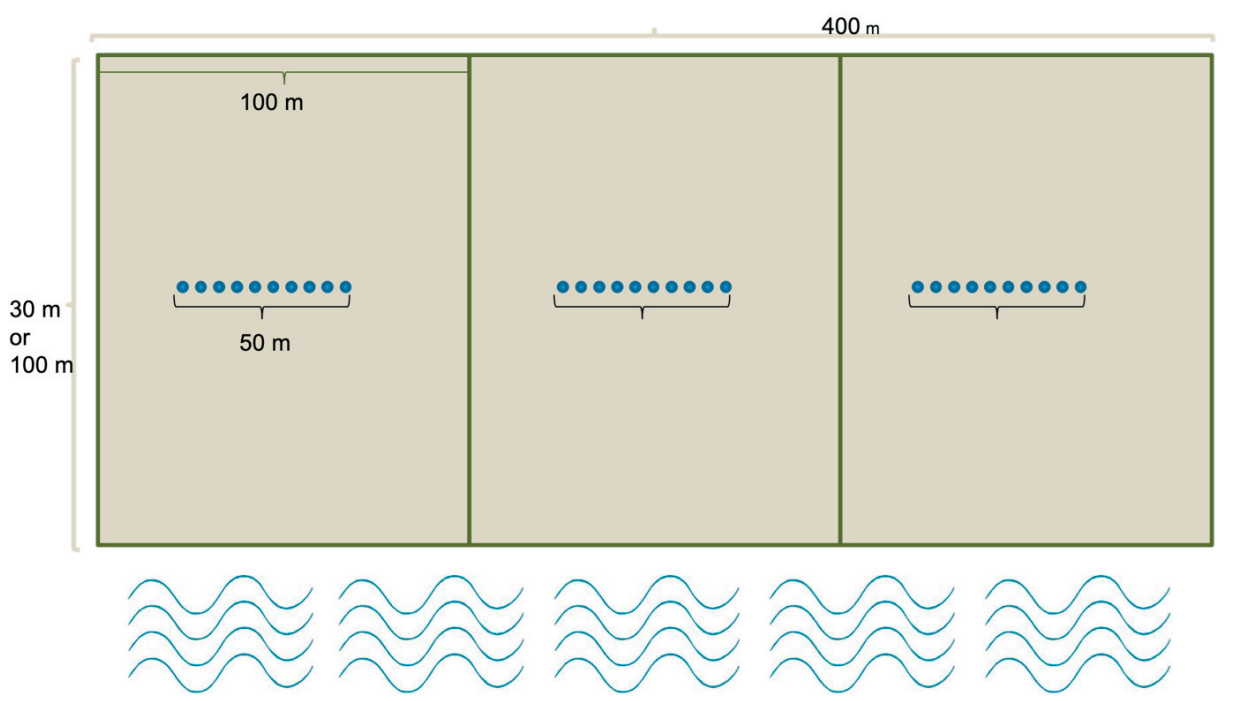

Figure 2. Graphic representation of pitfall trap sampling distribution in each study site of the riparian forest in the region of Volta Grande Reservoir, Brazil. Each blue dot in the picture represents the pitfall traps. The blue waves represent the water line, in the reservoir. Numbers represent the size of the plots in each sampling site.

Figura 2. Representación gráfica del diseño de muestreo - distribución de trampas de caída en cada sitio de muestreo, del bosque ribereño en la región del Embalse Volta Grande, Brasil. Cada punto azul en la imagen representa las trampas de caída. Las ondas azules representan la línea del agua en el embalse. Los números representan el largo y el ancho del área muestreada en cada sitio.

\section{Statistical analyses}

Richness and abundance of morphospecies was obtained from the samples (please see sampling section). We performed generalized linear models (GLM) to determine whether the richness of trophic groups (how many trophic groups we found in each taxon or study site), our response variable, is correlated to the richness and abundance of species. We use GLM for each of the 16 considered taxonomic groups and for the whole invertebrate community. We analyzed each sampling site separately. We consider each transect per month as independent cases in GLM. We used the structure of quasi-Poisson errors and submitted all GLM to residual analysis to evaluate the adequacy of error distribution (Crawley 2002). The analyses were performed with the program $R$.

\section{Results}

We sampled 28558 individuals of soil macroinvertebrates (here considered as abundance) of 16 taxonomic groups, representing two phyla, five classes and 451 morphospecies (here considered as richness) (Table 2 and Supplementary Material Table SM1). Coleoptera was the most abundant taxa and the one with the greatest richness of morphospecies and trophic groups (48.5\% and $28.3 \%$, respectively). Hymenoptera was the second most abundant and rich group (21.3\% and $16.3 \%$, respectively). Diptera (10\%), Orthoptera (8.5\%), Dermaptera (4.3\%) and Araneae $(2.5 \%)$ also showed a great abundance (Table 2 and Supplementary Material Table SM1).

Among the trophic groups found, the greatest abundance was for mycetophages $(27 \%)$ comprising mainly Hymenoptera (Formicidae, Atta sp.). The second most abundant trophic group was formed by organisms classified here as primary predators $(17.4 \%)$, consisted mainly of spiders, but also included some morphospecies of Hymenoptera, Coleoptera, Pseudoscorpiones, Chilopoda and Hemiptera. Saprophagous organisms were also abundant among the sampled invertebrates (13\%) (Table 2).

Richness and abundance of trophic groups were not related to richness $\left(\mathrm{F}_{1,13}=1.27 ; \mathrm{P}=0.27\right)$ but marginally to abundance of morphospecies $\left(\mathrm{F}_{1,13}=3.67 ; \mathrm{P}=0.07\right)$ when we analyzed the whole community. However, when we analyzed each taxonomic group individually, richness of morphospecies was positively related with richness of trophic groups $\left(\mathrm{F}_{1,14}=14.70 ; \mathrm{P}<0.01\right)$ (Figure 3). Taxonomic richness and abundance and trophic group richness from the restored sites are not significantly different to the reference sites (Figure 4). 
Table 2. Species richness and abundance of taxonomic and trophic groups of the soil macrofauna sampled in the restored areas of Volta Grande Reservoir, Brazil.

Tabla 2. Riqueza de especies y abundancia de grupos taxonómicos y de grupos tróficos de la macrofauna del suelo muestreada en las áreas restauradas del Embalse Volta Grande, Brasil.

\begin{tabular}{llccc}
\hline Taxonomic group & Trophic groups $\ddagger$ & Abundance (n) & Abundance (\%) & $\begin{array}{c}\text { Species } \\
\text { richness }\end{array}$ \\
\hline Blattodea & Omn & & 1.7 & 12 \\
Coleoptera & Sap, Myc, Her, PP, Cop, Omn & 13887 & 48.4 & 130 \\
Dermaptera & Omn & 1246 & 4.3 & 7 \\
Diptera & Sap, Fru, PP, Nec, Her & 2816 & 9.8 & 28 \\
Hemiptera & Phy, PP, SP, Sap & 240 & 0.8 & 41 \\
Hymenoptera & PP, SP, Omn, Her, Pol, Par, Myc, Nec & 6098 & 21.3 & 75 \\
Lepidoptera & Nec, Sap, Fru & 172 & 0.6 & 28 \\
Orthoptera & Her, Omn & 2427 & 8.4 & 29 \\
Araneae & PP, SP & 716 & 2.5 & 50 \\
Opiliones & Omn & 23 & 0.2 & 11 \\
Pseudoscorpiones & PP & 17 & 0.2 & 7 \\
Scorpiones & SP & 10 & 0.2 & 6 \\
Chilopoda & PP & 12 & 0.1 & 6 \\
Diplopoda & Det & 235 & 0.8 & 11 \\
Mesogastropoda & Her & 63 & 0.2 & 3 \\
Pulmonata & Her & 140 & 0.5 & 7 \\
\hline
\end{tabular}

$\ddagger$ For a description of the abbreviations of trophic groups, see Table 1.

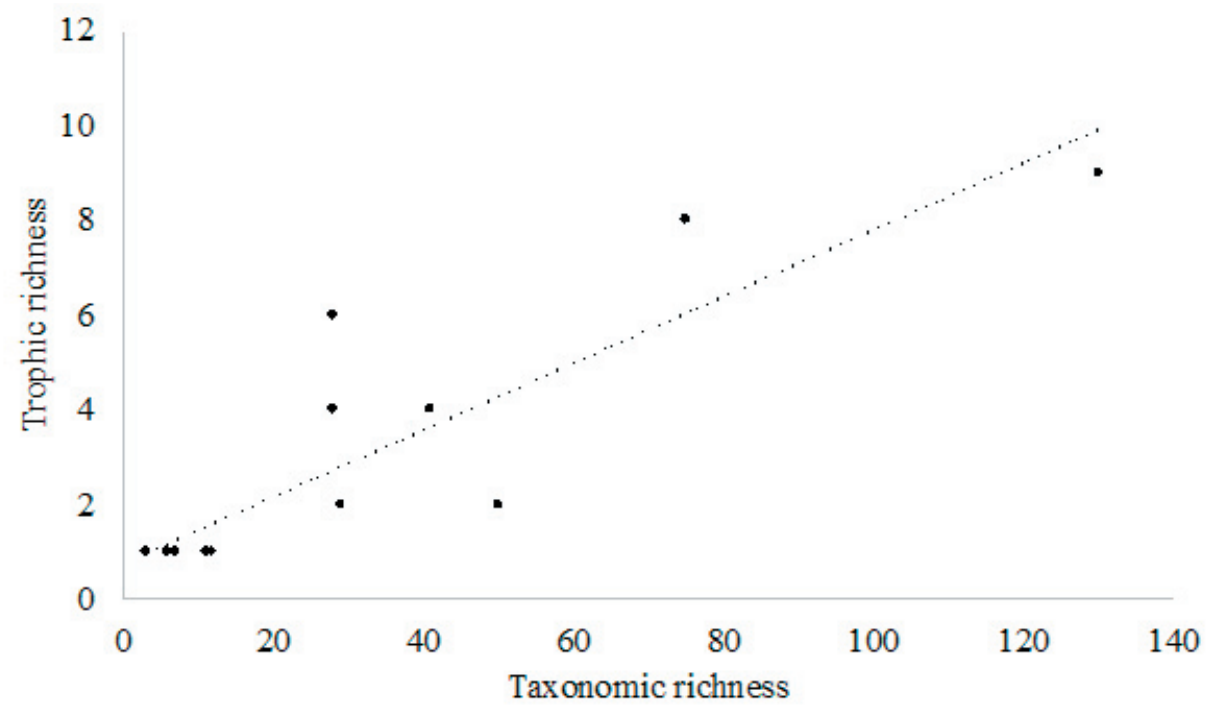

Figure 3. Relationship between richness of morphospecies (taxonomic richness) richness of trophic groups of invertebrates of soil, sampled in the riparian fragments of forest in the region of Volta Grande Reservoir, Brazil.

Figura 3. Relación entre la riqueza de morfoespecies (riqueza taxonómica) y la riqueza de grupos tróficos de invertebrados del suelo, muestreados en los fragmentos ribereños de bosque en la región del Embalse Volta Grande, Brasil. 

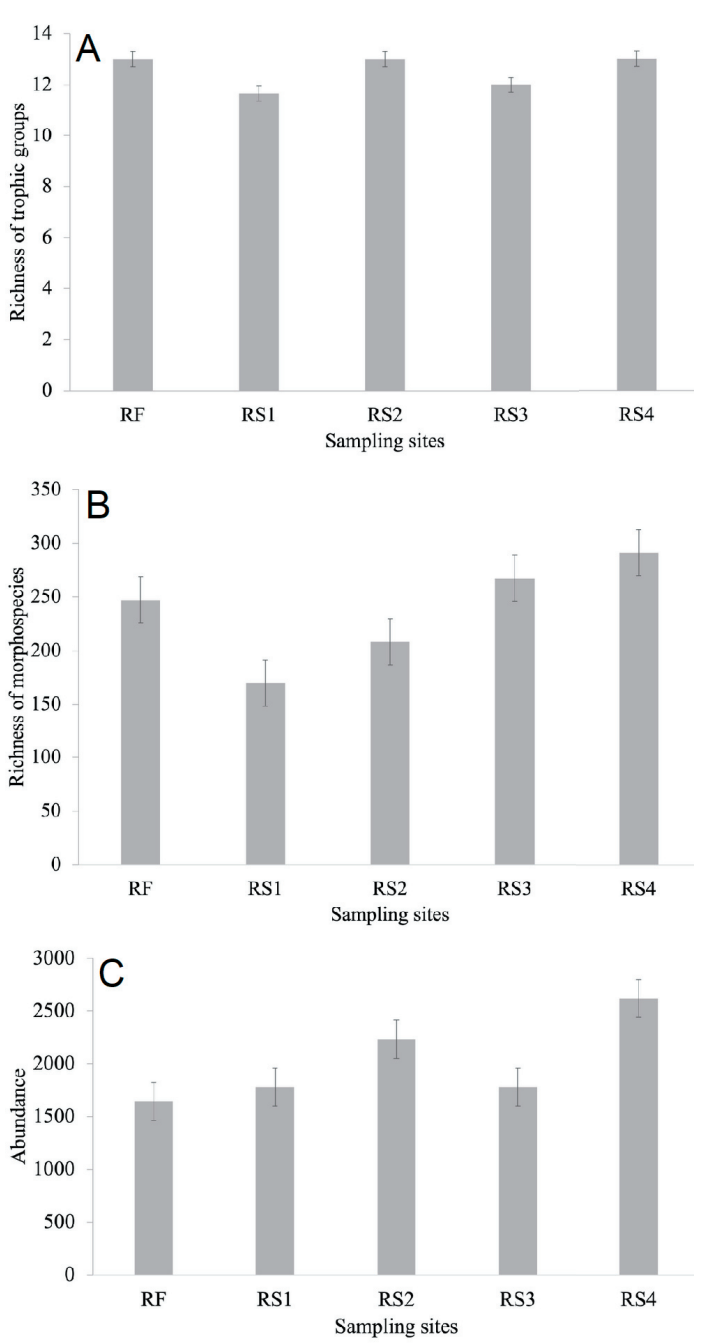

Figure 4. Representation of richness of trophic groups (A), taxonomic richness (B) and abundance (C) of the macrofauna of soil in the restored and in the reference site, in the riparian fragments of forest in the region of Volta Grande Reservoir, Brazil. RF: reference site; RS1 to RS4: restored sites.

Figura 4. Representación de la riqueza de grupos tróficos (A), riqueza taxonómica (B) y abundancia (C) de la macrofauna del suelo en el sitio restaurado y en el de referencia, en los fragmentos ribereños de bosque en la región del Embalse Volta Grande, Brasil. RF: sitio de referencia; RS1 a RS4: sitios restaurados.

\section{Discussion}

We found that richness of taxonomic and trophic groups was satisfactorily restored and comparable to older restored areas of Riparian Forest in Brazil, suggesting the recovery of the edaphic invertebrate community. So, our hypotheses that restoration, after 10 years, will recover the community in riparian ecosystems was confirmed. The richness observed in our restored sites was similar to our reference sites (30 years since the natural restoration started) and maybe reflects environmental stability due to higher plant diversity, low microclimate oscillation, soil nutrient content and litter quality according to Vasconcellos et al. (2013) and Menezes et al. (2009). Antonini et al. (2016) also reported higher invertebrate richness and abundance (in above and below ground groups) in the same studied sites. According to Messias et al. (2016) the variables used to measure the progress of the ecological succession, in the same sites than our study (e.g., tree diversity, richness of functional groups of plants, leaf litter production) show that general environmental structure is comparable to the native areas of the region. Also, Amazonas et al. (2017), studying the macrofauna of soil across a chronosequence of tropical forest restoration, found that the density of macrofauna did not increase linearly along the chronosequence, but it was correlated with increase in canopy cover. These authors also found that the overall diversity is characterized by high dominance of social insects and evenness among the other groups.

Insecta was the dominant taxa in the soil in our studied sites with high richness and abundance of groups, as expected for forests in high stage of ecological succession after restoration. Some authors have argued that the recovery of habitat complexity on restored forests increased the richness and abundance of arthropods (including insects) (see Bandeira and Harada 2008; Soares et al. 2013; Watts and Mason [2015]). Antonini et al. (2016) also found a high richness of insects (i.e., bees, wasps, and ants) in the same restored sites, and reported that the values are comparable to the natural areas in the Cerrado region. Hymenoptera (mainly ants) was the most abundant group, mostly composed by leaf-cutting ants. Species of this group are dominant in many tropical forests and able to use a broad range of resources (Ho®lldobler and Wilson 1990; Boaretto and Forti 1997). Antonini et al. (2016) also reported a high richness of arboreal ant species distributed in different functional groups in the recovered areas of Volta Grande Reservoir. The high abundance of Hymenoptera is also often associated with recovering environments because of the new habitats that are created over the ecological succession (Vasconcelos et al. 2013; Menezes et al. 2009). These authors also found Hymenoptera (dominated by ants) representing almost half of the individuals 
collected in restored riparian forests. This group is of great ecological and economic importance because it collects plant material to grow the symbiotic fungus that serves as their food (Vasconcelos et al. 2013). Previous studies have indicated that in secondary forests, ants can have positive impacts on the chemical and physical structure of the soil and potentially benefit vegetation (Boaretto and Forti 1997; Farji-Brener 2003).

We found, as expected, higher diversity of groups of insects with high number of species, that also represented more trophic groups. For example, Coleoptera was the most diverse group in the study site, with high number of functions described. This was expected for this group, since is one of the most diverse in tropical forest soils (Gullan and Craston 2008). Besides, Coleoptera is an important group of soil invertebrates because they perform a variety of different functions in ecosystems since they encompass a diverse range of diets, including leaves, vegetal remains, animal waste and other arthropods (Gullan and Craston 2008). Also, it is important to notice that the composition can change, since some species are more sensitive to habitat changes and therefore are associated with native or more preserved forests while other species, more generalist, are associated with the recovering forests (secondary). According to (Vasconcelos et al. 2013) this is because this group are sensitive to physical and chemical attributes of soil that change over the ecological succession.

Taxonomic diversity was not related to trophic diversity, when analyzing the entire community of macroinvertebrates. This indicates that a large number of morphospecies are functionally redundant in trophic roles, that is, multiple morphospecies with similar trophic niches (e.g., herbivores and omnivorous) (Andren et al. 1995; Bengtsson 1998). In a community with greater functional redundancy, the role of any taxon can be at least partially replaced by another taxon. This high overlap allowed the community to maintain its structure under disturbances (communities with high stability) and difficult invasion by exotic species (Chapin III et al. 1997; Loreau et al. 2001; Petchey 2003).

However, when we analyzed the trophic functions among the invertebrates within each taxonomic group, we observed that the greater the richness, the greater the number of functions observed. This means that is likely that several trophic groups influences similar services and functions of the ecosystem (Sylvain and Wall 2011). For example, although Coleoptera and Hymenoptera were groups with high abundance and richness of species and trophic groups, we found some degree of specialization, with some species developing a particular function in the environment (Gullan and Craston 2008), with some species of Coleoptera, acting as secondary seed dispersal (Nunes et al. 2018) and some species of Hymenoptera (wasps) acting as primary predator. These examples may explain our results that show the positive association of species richness and abundance with the richness of trophic groups, which indicates the particular importance of each taxonomic group for the ecosystem functions in those recovered habitats.

\section{Conclusion}

In this study, we showed how the diversity of taxonomic groups was related to the diversity of trophic groups. The forest recovery of the studied areas allowed to the taxonomic and trophic composition in our study area to be like the composition of natural areas. The descriptors of the structure of the soil macroinvertebrate community (richness and abundance) proved to be very useful to understand how taxonomic diversity are related to functional diversity. Our results also highlight the importance of the variation of taxonomic and functional diversity suggesting this approach for future studies on edaphic invertebrates and ecological restoration.

Acknowledgments. We thank the Programa de Pós-Graduação em Ecologia de Biomas Tropicais/UFOP for their support in the execution of this study. We thank Fapemig/ CEMIG APQ 3055/11 for the financial assistance, CAPES for providing a scholarship for $\mathrm{SB}$ and $\mathrm{CNPq}$ for providing scholarships for YA and RLF; Marina Beirão and Graziella França for helping us with statistics. Sabrina Martins Florêncio for the help with invertebrate's measurements. Matheus Jorge Correa, Adriele Prisca and Joice Paiva Vidigal Martins, for their help in field work. Erik Wild for the English Revision. 


\section{REFERENCES}

Alvares, C. A., J. L. Stape, P. C. Sentelhas, J. L. Gonsalves de M., and G. Sparovek. 2014. Köppen's climate classification map for Brazil. Meteorologische Zeitschrift 22:711-728. https://doi.org/10.1127/0941-2948/2013/0507.

Andren, O., M. Clarholm, and J. Bengtsson. 1995. Biodiversity and species redundancy among litter decomposers. Pp. 141-151 in H. Collins, G. Robertson and M. Klug (eds.). The significance and regulation of soil biodiversity. Kluwer, Dordrecht, Netherlands. https://doi.org/10.1007/978-94-011-0479-1_12.

Antonini, Y., B. Melo, D. B. Faria, G. F. Monteiro, G. J. Araújo, J. P. V. Martins, and S. Biondi. 2016. A importância da restauração das florestas na manutenção da comunidade de invertebrados: um caso de sucesso em Volta Grande. Pp. 89-98. in Y. Antonini and J. P. V. Martins (eds.). Restauração e conservação de matas ciliares em Reservatórios Hidroelétricos: importância para a conservação da biodiversidade e processos ecológicos. Nitro Editora, Belo Horizonte, MG, Brasil.

Araujo, G. J., R. Fagundes, and Y. Antonini. 2017. Trap-Nesting Hymenoptera and their network with parasites in recovered riparian forests. Neotropical Entomology 47:26-36. https://doi.org/10.1007/s13744-017-0504-4.

Amazonas, N. T., R. A. G. Viani, M. G. A. Rego, F. F. Camargo, R. T. Fujihara, and O. A. Valsechib. 2017. Soil macrofauna density and diversity across a chronosequence of tropical forest restoration in Southeastern Brazil. Brazilian Journal of Biology. 78:449-456. https://doi.org/10.1590/1519-6984.169014.

Baccaro, F. B., R. M. Feitosa, F. Fernandez, I. O. Fernandes, T. J. Izzo, J. L. P. Souza, and R. Solar. 2015. Guia para os gêneros de formigas do Brasil. Pp. 386. https://doi.org/10.5281/zenodo.32912.

Bandeira, A. G., and A. Y. Harada. 1998. Densidade e distribuição vertical de macroinvertebrados em solos argilosos e arenosos na Amazônia central. Acta Amazonica 28:191-204. https://doi.org/10.1590/1809-43921998282204.

Barrios, E. 2007. Soil biota, ecosystem services and land productivity. Ecological Economics 64:269-285. https://doi.org/ 10.1016/j.ecolecon.2007.03.004.

Bengtsson, J. 1998. Which species? What kind of diversity? Which ecosystem function? Some problems in studies of relations between biodiversity and ecosystem function. Applied Soil Ecology 10:191-199. https://doi.org/10.1016/ S0929-1393(98)00120-6.

Blankinship, J. C., P. A. Niklaus, and B. A. Hungate. 2011. A meta-analysis of responses of soil biota to global change. Oecologia 165:553-565. https://doi.org/10.1007/s00442-011-1909-0.

Boaretto, M. A. C., and L. C. Forti. 1997. Perspectivas no controle de formigas cortadeiras. Série Técnica IPEF 30:3146.

Chapin III, F. S., B. H. Walker, R. J. Hobbs, D. U. Hooper, J. H. Lawton, O. E. Sala, and D. Tilman. 1997. Biotic Control over the Functioning of Ecosystems. Science 277:500-504. https://doi.org/ 10.1126/science.277.5325.500.

Crawley, M. J. 2002. Statistical computing: an introduction to data analysis using S-Plus. Wiley. Pp. 761.

Dominati, E., M. Patterson, and A. Mackay. 2010. A framework for classifying and quantifying the natural capital and ecosystem services of soils. Ecological Economics 69:1858-1868. https://doi.org/10.1016/j.ecolecon.2010.05.002.

Farji-Brener, A. G. 2003. Why are leaf-cutting ants more common in early secondary forests than in old-growth tropical forests? An evaluation of the palatable forage hypothesis. Oikos 92:169-177. https://doi.org/10.1034/j.16000706.2001.920120.x.

Fraser, L. H., W. L. Harrower, H. W. Garris, S. Davidson, P. D. N. Hebert, R. Howie, A. Moody, D. Polster, O. J. Schmitz, A. R. E. Sinclair, B. M., Starzomski, T. P., Sullivan, R. Turkington, and D. Wilson. 2015. A call for applying trophic structure in ecological restoration. Restoration Ecology 23:503-507. https://doi.org/10.1111/rec.12225.

Gullan, P. J., and P. S. Craston. 2008. Os insetos: um resumo de entomologia. São Paulo: Roca. Pp. 440.

Heemsbergen, D. A., M. P. Berg, M. Loreau, J. R. van Hal, J. H. Faber, and H. A. Verhoef. 2004. Biodiversity Effects on Soil Processes Explained by Interspecific Functional Dissimilarity. Science 306:1019-1020. https://doi.org/0.1126/ science.1101865.

Hölldobler, B., and E.O. Wilson. 1990. The Ants (Springer-Verlag, Berlin). https://doi.org/10.1007/978-3-662-10306-7.

Jones, M. E., and N. Davidson. 2016. Applying an animal-centric approach to improve ecological restoration. Restoration Ecology 24:836-842. https://doi.org/10.1111/rec.12447.

Kollmann, J., S. T. Meyer, R. Bateman, T. Conradi, M. M. Gossner, M. de Souza Mendonça, G. W. Fernandes, J. M. Hermann, C. Koch, S. C. Müller, Y. Oki, G. E. Overbeck, G. B., Paterno, M. F. Rosenfield, T. S. P. Toma, and W. W. Weisser. 2016. Integrating ecosystem functions into restoration ecology - recent advances and future directions. Restoration Ecology 24:722-730. https://doi.org/10.1111/rec.12422.

Lach, L., C. L. Parr, and K. L. Abbott. 2010. Ant Ecology. E. O. Wilson, Ed. Oxford University Press. Pp. 429. https: //doi.org/10.1093/acprof:oso/9780199544639.001.0001.

Lavelle, P., T. Decaëns, M. Aubert, S. Barot, M. Blouin, F. Bureau, P. Margerie, P. Mora, and J. P. Rossi. 2006. Soil invertebrates and ecosystem services. European Journal of Soil Biology 42:S3-S15. https://doi.org/10.1016/ j.ejsobi.2006.10.002.

Loreau, M., S. Naeem, P. Inchausti, J. Bengtsson, J. P. Grime, A. Hector, D. U. Hooper, M. A. Huston, D. Raffaelli, B. Schmid, D. Tilman, and D. A. Wardle. 2001. Biodiversity and Ecosystem Functioning: Current Knowledge and Future Challenges. Science 294:804-808. https://doi.org/10.1126/science.1064088.

Martins, R., and Y. Antonini. 2016. Can pollination syndromes indicate ecological restoration success in tropical forests? Restoration Ecology 24:373-380. https://doi.org/10.1111/rec.12324.

Menezes, C. E. G., M. E. F. Correia, M. G. Pereira, I. Batista, K. M. Rodrigues, W. H. Couto, L. H. C. Anjos, and I. P. Oliveira. 
2009. Macrofauna edáfica em estádios sucessionais de Floresta Estacional Semidecidual e pastagem mista em Pinheiral (RJ). Revista Brasileira de Ciência do Solo 33:1647-1656. https://doi.org/10.1590/S0100-06832009000600013.

Messias, M. C. T. B., Y. Antonini, and A. R. Kozovits. 2016. Indicadores de sucessão: como medir o sucesso de um programa de restauração ambiental. Pp. 89-98 in Y. Antonini and J. P. V. Martins (eds.). Restauração e conservação de matas ciliares em Reservatórios Hidroelétricos: importância para a conservação da biodiversidade e processos ecológicos. Nitro Editora, Belo Horizonte, MG, Brasil.

Moldenke, A. R. 1994. Arthropods. Pp. 517-542 in Methods of Soil Analysis: Part 2 - Microbiological and Biochemical Properties. SSSA Book ed. Soil Science Society of America. https://doi.org/10.2136/sssabookser5.2.c24.

Peipoch, M., M. Brauns, F. R. Hauer, M. Weitere, and H. Valett. 2015. Ecological Simplification: Human Influences on Riverscape Complexity. BioScience 65:1057-1065. https://doi.org/10.1093/biosci/biv120.

Petchey, O. L. 2003. Integrating methods that investigate how complementarity influences ecosystem functioning. Oikos 10:323-330. https://doi.org/10.1034/j.1600-0706.2003.11828.x.

Punzo, F. 1994. The Biology of the Spider Wasp Pepsis Thisbe (Hymenoptera: Pompilidae) From Trans Pecos, Texas. I. Adult Morphometrics, Larval Development and the Ontogeny of Larval Feeding Patterns. Psyche: A Journal of Entomology 101:229-241. https://doi.org/10.1155/1994/70378.

R Studio. 2016. R Studio: Integrated Development for R. RStudio, Inc., Boston, MA.

Ruiz-Jaen, M. C., and T. Mitchell Aide. 2005. Restoration Success: How Is It Being Measured? Restoration Ecology 13: 569-577. https://doi.org/10.1111/j.1526-100X.2005.00072.x.

Sheean, V. A., A. D. Manning, and D. B. Lindenmayer. 2012. An assessment of scientific approaches towards species relocations in Australia. Austral Ecology: 37:204-215. https://doi.org/10.1111/j.1442-9993.2011.02264.x.

Soares, L. G. S., A. F. Koken, M. B. Van der Timo, and R. P. da Silva. 2013. Fauna de invertebrados em cavernas de calcário na região de Córrego Fundo, Minas Gerais, Brasil. Revista Eletrônica de Biologia 6:48-68.

Stork, N. E., and P. Eggleton. 1992. Invertebrates as determinants and indicators of soil quality. American Journal of Alternative Agriculture 7:38-47. https://doi.org/10.1017/S0889189300004446.

Sylvain, Z. A., and D. H. Wall. 2011. Linking soil biodiversity and vegetation: Implications for a changing planet. American Journal of Botany B:517-527. https://doi.org/10.3732/ajb.1000305.

Triplehorn, C., and N. Johnson. 2005. Borror and Delong's Introduction to the Study of Insects. Cengage. Pp. 888.

Vasconcellos, R. L. F., J. C. Segat, J. A. Bonfim, D. Baretta., and E. J. B. N. Cardoso. 2013. Soil macrofauna as an indicator of soil quality in an undisturbed riparian forest and recovering sites of different ages. European Journal of Soil Biology 58:105-112. https://doi.org/ 10.1016/j.ejsobi.2013.07.001.

Watts, C. H., and N. W. H. Mason. 2015. If we build - they mostly come: Partial functional recovery but persistent compositional differences in wetland beetle community restoration. Restoration Ecology 23:555-565. https://doi.org/ 10.1111/rec.12227. 